\title{
PELATIHAN PEMBERDAYAAN JUS SIRSAK SEBAGAI MINUMAN KESEHATAN OLAHAN ALAMI PENCEGAH KANKER
}

\author{
Lesi Hartati $^{{ }^{*}}$, Asmawati $^{2}$, Rum Hendarmin ${ }^{3}$ Lili Syafitri $^{4}$ \\ $1,2,3$ \\ Fakultas Ekonomi Akuntansi, Universitas Indo Global Mandiri Palembang \\ ${ }^{4}$ Fakultas Ekonomi Manajemen, Universitas Indo Global Mandiri Palembang \\ E-mail: ${ }^{1)}$ hertatilesi@yahoo.co.id , ${ }^{2)}$ asmawati@uigm.ac.id, ${ }^{3)}$ rumhendarmin@uigm.ac.id, ${ }^{4)}$ \\ lilisahfitri@uigm.ac.id
}

\begin{abstract}
Abstrak
Indonesia adalah tanah surga dimana tumbuhan bisa tumbuh subur dan banyak manfaat untuk kehidupan manusi. Kekayaan alam di Indonesia dapat diolah guna menopang ekonomi keluarga dan bermanfaat untuk kesehatan serta berguna untuk pengobatan berbagai penyakit serta mengandung banyak vitain yang dibutuhkan oleh organ tubuh untuk menambah energi. Manfaat tumbuhan sirsak cukup besar untuk kesehatan badan disamping buahnya enak dimakan begitu saja. Sirsak cepat tubuh diman-mana kadangkalah tumbuh sendiri dihalaman rumah, namun kadangkala sengaja ditanam oleh masyarakat untuk perkebunan yang menghasilkan uang. Selain buah sirsak pun daun sirsak juga untuk mengobati kolestorel jika direbus dengan rempah lain seperti daun siri dan garam sedikit. Proses pembuatan jus sirsak cukup mudah jika buahnya sudah mateng, namun buah sirsak yang masih mentahpun bisa digoreng rasanya pulen seperti ubi-ubian. Peluang usaha menanam bibit Sirsak cukup menjanjikan disamping buah daunpun bermanfaat untuk kesehatan yang banyak mengandung obat untuk kebutuhan tubuh.
\end{abstract}

Kata kunci: Jus Sirsak, Minuman Kesehatan, Olahan Alami, Pencegah Kanker

\begin{abstract}
Indonesia is a paradise for plants, with numerous advantages for human life. It is possible to process Indonesia's natural resources to support the family economy while also benefiting health and being useful in treating various diseases, and many of these resources contain the vitamins that the body's organs require to increase energy. The health advantages of soursop plants are substantial, and the fruit is tasty to consume as is. Sometimes it grows naturally in people's yards; at other times, it is planted intentionally by the community for economic purposes. Apart from the fruit, soursop leaves can also be used to treat cholestorel when combined with additional spices such as betel leaves and a pinch of salt. Making soursop juice is simple if the fruit is ripe, although soursop fruit that is not ripe yet can be fried and the taste is similar to sweet potatoes. The business potential related with soursop seed planting are considerable. Along with the fruit, the leaves are beneficial for health since they contain a variety of vitamins that the body need.
\end{abstract}

Keywords: Soursop Juice, Healthy Drinks, Natural Processed, Cancer Prevention 


\section{PENDAHULUAN}

Kewirausahaan bertujuan menciptakan lagba dari hasil kegiatan usaha guna meningkatkan pendapatan masyarakat ekonomi lemah dengan memanfaatkan peluang yang ada dissekitar kita, seperti manfaat buah Sirsak (Annona Muricata). Buah-buahan yang ada disekitar kita sangat bermanfaat dan memperi peluang jika dikelola dengan baik yang merupakan salah satu tanaman buah yang berasal dari Karibia, Amerika Tengah dan Amerika Selatan. Buah sirsak rasanya manis agak asam sehingga sering dipakai sebagai bahan jus buah. Daging buahnya kaya akan serat (Teyler, 2002). Daging buah sirsak yang matang dapat dimakan segar atau dibuat jus. Saat ini, sebagian besar sirsak dikonsumsi dalam bentuk minuman olahan (Ashari, 2006).

Buah sirsak terdiri atas 67,5\% daging buah yang dapat dimakan, $20 \%$ kulit, 8,5\% biji, dan $4 \%$ empulur. Biji pada tanaman sirsak bersifat racun dan dapat dimanfaatkan sebagai insektisida alami, sedangkan daun sirsak dapat bermanfaat dalam menghambat pertumbuhan sel kanker dengan menginduksi apoptosis, analgetik, anti disentri, anti asma, antihelmitic, dilatasi pembuluh darah, menstimulasi pencernaan, dan mengurangi depresi. Batang dan daun memiliki kandungan zat annonaceous acetogenins yang menunjukkan sitotoksik aktif melawan sel kanker, selain mengandung zat annonaceous acetogein, terdapat kandungan flavonoid, Tanin, dan saponin pada ekstrak air daun sirsak, yang berfungsi dalam menghambat pertumbuhan tumor. Selain sifat anti kanker, sirsak juga memiliki sifat anti bakteri, anti jamur, dan efektif dalam melawan berbagai jenis parasit atau cacing, bahkan sirsak dapat mengobati tekanan darah tinggi, depresi, dan stress (Dahliani, 2015; Maria, 2013).

Sirsak diperkaya dengan vitamin, mineral, dan serat pangan. Mengonsumsi $100 \mathrm{~g}$ daging sirsak dapat mencukupi kebutuhan serat harian sebesar 13\%. Dalam $100 \mathrm{~g}$ daging sirsak mengandung sekitar $20 \mathrm{mg}$ Vitamin C. Vitamin C dapat membantu menjaga daya tahan tubuh, menghindari diri dari radikal bebas, dan menghindari penuaan dini. Selain itu, buah sirsak banyak mengandung zat mineral penting seperti fosfor sekitar $27 \mathrm{mg}$ dan kalsium $14 \mathrm{mg}$ per $100 \mathrm{~g}$ pada buahnya. Kedua kandungan ini adalah nutrisi yang penting untuk kesehatan tulang (Prasetyorini et al., 2014). Munculnya ide untuk menjawab permasalahan yang menarik untuk diteliti yaitu: Kandungan gizi dari Buah Sirsak seperti :

1) Mengandung molekul antioksidan

Molekul dengan sifat antioksidan dapat menangkal radikal bebas, atom tidak stabil yang dapat merusak sel dan menyebabkan penyakit berbahaya. Sirsak merupakan salah satu sumber antioksidan yang baik. Beberapa jenis molekul antioksidan di sirsak, yakni, tannin, saponin, pitosterol, flavonoid, anthraquinone. Secara keseluruhan, sirsak dapat menjaga kesehatan. Penelitian lebih lanjut diperlukan, untuk mengkaji manfaat buah sirsak untuk penyakit tertentu (Naylor \& Florida, 2003)

2) Memiliki sifat anti-inflamasi

Inflamasi sebenarnya merupakan mekanisme tubuh untuk melawan infeksi. Walau begitu, inflamasi yang kronis dapat memicu berbagai penyakit. Beberapa penelitian yang dilakukan pada hewan menyimpulkan bahwa sirsak berpotensi mengurangi pembengkakan, serta membantu meringankan inflamasi atau peradangan.

3) Membantu menurunkan kadar gula darah 


\section{PORTAL RISET DAN INOVASI PENGABDIAN MASYARAKAT (PRIMA) \\ VOLUME 1 ISSUE 1 (2021)}

Manfaat sirsak lainnya yakni menstabilkan kadar gula darah. Seperti yang telah diketahui, tingginya kadar gula merupakan kondisi yang berbahaya, karena dapat memicu berat badan berlebih (obesitas), serta penyakit jantung. Beberapa penelitian menemukan, sirsak dapat menstabilkan tingginya kadar gula dalam darah tersebut. Walau riset ini juga dilakukan pada hewan, bukan tak mungkin manfaat buah sirsak ini juga berlaku untuk manusia.

4) Menurunkan tekanan darah

Sirsak telah dikenal masyarakat sebagai tanaman obat, untuk menurunkan tekanan darah. Tekanan darah dapat meningkatkan risiko terhadap penyakit jantung, diabetes, dan stroke. Dalam sebuah riset yang dimuat jurnal Pharmaceutical Biology, sirsak memiliki potensi untuk menurunkan tekanan darah, tanpa berefek menaikkan detak jantung.

5) Membunuh sel kanker

Khasiat sirsak lainnya, yakni untuk melawan sel kanker. Beberapa penelitian telah membuktikan hal ini, walau riset-riset tersebut masih dilakukan dengan uji tabung di labotarium, seperti dengan memasukkan ekstrak buah sirsak ke dalam sel leukemia (kanker darah).

6) Melawan bakteri

Selain memiliki molekul antioksidan, sirsak juga diyakini dapat melawan bakteri. Beberapa riset, yang juga dilakukan dengan uji tabung laboratorium, menyimpulkan bahwa buah berdaging putih ini dapat melawan bakteri penyebab kolera, gigi berlubang, dan gingivitis (peradangan pada gusi). Tentunya, penelitian lebih lanjut diperlukan, untuk menguatkan bukti mengenai manfaat sirsak ini.

\section{METODE PENELITIAN}

Dalam rangka pelaksanaan pengabdian kepada masyarakat, agar dapat memberikan nilai tambah, baik secara sosial maupun ekonomi, agar masyarakat dapat mengetahui betapa pentingnya berbagi kepada yang membutuhkan. Srategi yang digunakan dengan memanfaatkan lingkungan sekitar dan teknologi seperti blender guna memisahkan bulirbulir atau sari dari buah dan mencampurnya, menghancurkannya, dan melembutkannya, hanya dalam satu alat saja. ada bagian buah tidak terdapat ampas, (Hertati \& Safkaur, 2020). Capaian pelatihan kegiatan kewirausahaan agar mampu melakukan praktik kel wirausahaan dengan pemahaman konsep wirausaha yang Komprehensif. Bagi masyarakat kecil menumpbuhkan kegiatan yang menghasilkan uang bagi yang telah memiliki usaha dapat mengikuti program ini dengan capaian akhir pengembangan usahanya atau inovasi usahanya (Hertati, Asmawati, et al., 2021).

Adapun Capaian Pelatihan Kewirausahaan ini adalah: 1.Technical Skill (Mampu memproduksi barang, jasa/informasi), 2.Conceptual Skill (Mampu merumuskan tujuan, kebijakan dan strategi usaha) 3.Managerial Skill (Mampu menjalankan fungsi perencanaan, pengorganisasian, penggerakan dan pengawasan agar fungsi-fungsi berjalan dengan baik) ,4.Human Skill (Mampu mencari, memelihara dan mengembangkan relasi, mampu berkomunikasi dan negosiasi), 5.Decision Making Skill (Mampu menganalisis dan merumuskan berbagai masalah untuk dicarikan jalan keluar sebagai pemecahan), 6 . Technology Skill ( Mampu mengadaptasi dan menggunakan tehnology),7. Marketing Skill (Mampu menemukan pasar atau pelanggan serta mampu menentukan harga yang tepat), 8. Finansial Skill (Mampu memperoleh sumber dana dan cara menggunakannya), 9. Initiative 
\& Enterprise Skill (Mampu untuk memulai dan menindak lanjuti suatu rencana dan usaha, dengan penuh semangat dan tekad yang kuat. Memiliki atau menunjukkan inisiatif, kreatif dan inovatif 10. Time Managerial Skill (Ketrampilan mengatur waktu)

Strategi yang diperlukan untuk mencapai tujuan dengan memperhatikan misi. Kegiatan Pelaksanaan Pengabdian Kepada Masyarakat ini dilakukan pada bulan Nopember, Desember, 2021 dan Januari 2022 atau tahun dapat tabel jadwal kegiatan pelaksanaan. (Hertati, Feri, et al., 2021; Khristianto, 2008; Kuncoro, 2001).

Tabel 1 Metode Pelaksanaan

\begin{tabular}{|c|l|l|l|}
\hline No & \multicolumn{2}{|c|}{ Metode Pelaksanaan } & \multicolumn{1}{|c|}{ Indikator Pelaksanaan } \\
\hline 1 & Tahap & Bentuk & Kuesioner pretest dan posttest \\
\hline 2 & Sosialisasi & Pelatihan di rumah masyarakat & Kuesioner pretest dan posttest \\
\hline 3 & Pengajaran & Pengolahan buah Sirsak & $\begin{array}{l}\text { Mampu Menguasai pangsa } \\
\text { pasar }\end{array}$ \\
\hline 4 & Aflikasi & Pelatihann obat alami kesehatan & $\begin{array}{l}\text { Meningkatkan Penghasilan } \\
\text { usahawan }\end{array}$ \\
\hline 5 & Evaluasi & Soslusi pengembangan Produk baru & \\
\hline
\end{tabular}

Keberhasilan sosialisasi dapat dilihat dari hasil jawaban kuisioner pre-test (sebelum sosialisasi) dan post-test (sesudah sosialisasi) dengan tingkat keberhasilan 100\%, sedangkan bagi wirausaha yang sudah tua sibuk mencatat dari apa yang di Sosialisasi. Pengabdian masyarakayt ini menggunakan biaya secara perguruan tinggi Indo Global Mandiri dilakukan dengan virtual diraenakan musim wabah Pademi Covid-19 dan jarak yang cukup jauh.

Lokasi pengabdian pada masyarakat ini berada pada gambar peta seperti tampak dibawah ini

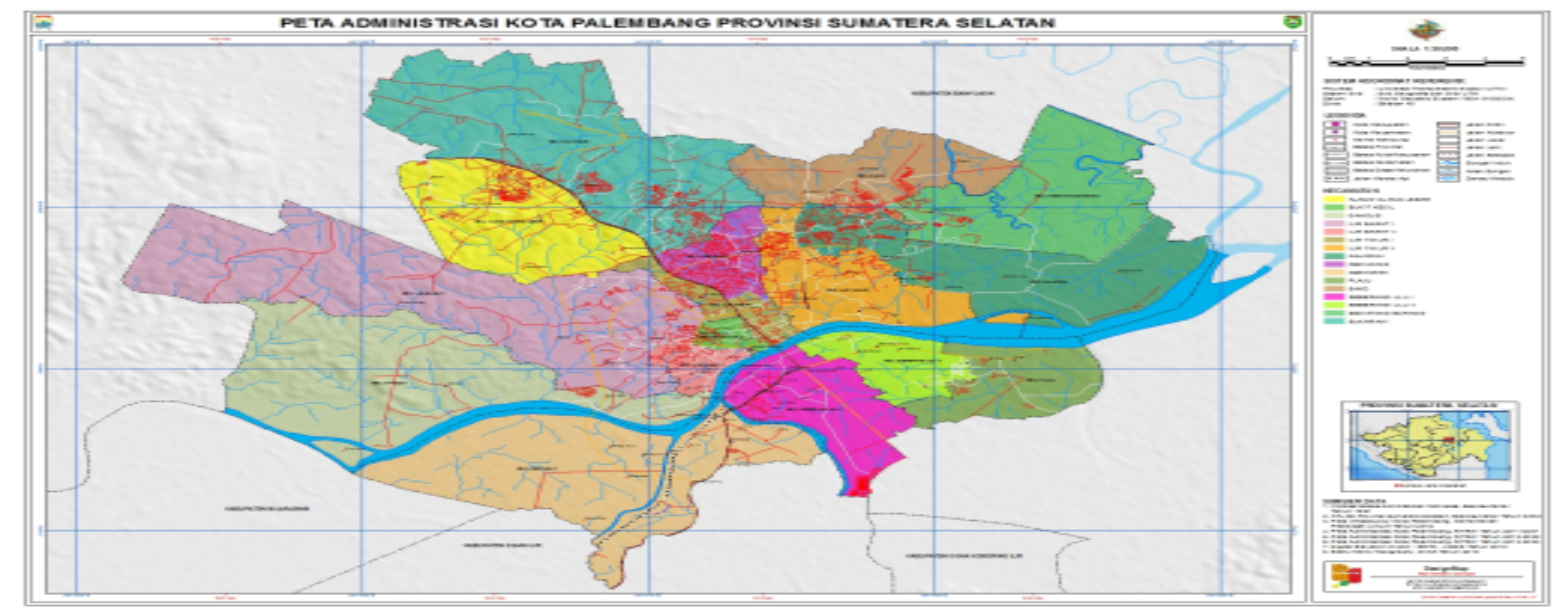

Gambar 1 Lokasi Pengabdian

Pelaksanaan dan pengabdian ini berlokasi di Kota Palembang Kecamatan Ilir Barat 1 Dikarenakan protokoler kesehatan selama Covid19 yang mengharuskan untuk jaga jarak, sehingga tidak memungkinkan kegiatan penyuluhan diikuti oleh dosen, mahasiswa. Kemudian maksud diadakannya penyuluhan dan menjelaskan materi tentang "Pelatihan 


\section{Pemberdayaan Jus Sirsak Sebagai Minuman Kesehatan Olahan Alami Pencegah Kanker"}

\section{HASIL DAN PEMBAHASAN}

\subsection{Masyarakat Sasaran}

Masyarakat terlihat antusias mengikuti penyuluhan terutama saat dijelaskan terkait manfaat Jus buah Sirsak terhadapa kesehatan dan obat penyakit kangker. Tahap terakhir dilakukan evaluasi berupa penyebaran kuesioner post-test untuk melihat sejauh mana pemahaman masyarakat terhadap materi yang dipaparkan. Sama halnya dengan pre-test, post-test berlangsung selama 5 menit. Pre-test dan post-test menggunakan skala likert dengan rincian yaitu sangat tidak paham (5), cukup paham (4), tidak paham (3), paham (2), sangat paham (1). Berdasarkan jawaban masyarakat dari pengisian pre-test dan post-test didapat data seperti terlihat di Tabel 1.

Tabel 1 Rekapitulasi Jawaban masyarakat, 2022

\begin{tabular}{|c|c|c|c|c|}
\hline No. & Indikator & Kategori & Jawaban & $\begin{array}{l}\text { Persentase } \\
(\%)\end{array}$ \\
\hline 1 & \multirow{5}{*}{$\begin{array}{l}\text { Bapak Ibuk memahami } \\
\text { Manfaat Buah Sirsak }\end{array}$} & Sangat Tidak Paham & 0 & 0 \\
\hline 2 & & Cukup Paham & 0 & 0 \\
\hline 3 & & Tidak Paham & 0 & 0 \\
\hline 4 & & Paham & 0 & 0 \\
\hline 5 & & Sangat Paham & 100 & $100 \%$ \\
\hline 1 & \multirow{5}{*}{$\begin{array}{l}\text { Manfaat Jus Sirsak } \\
\text { Drink Kesehatan }\end{array}$} & Sangat Tidak Paham & 0 & 0 \\
\hline 2 & & Cukup Paham & 0 & 0 \\
\hline 3 & & Tidak Paham & 0 & 0 \\
\hline 4 & & Paham & 0 & 0 \\
\hline 5 & & Sangat Paham & 100 & $100 \%$ \\
\hline 1 & \multirow{5}{*}{$\begin{array}{c}\text { Olahan Alami } \\
\text { Mencegah Kanker }\end{array}$} & Sangat Tidak Paham & 0 & 0 \\
\hline 2 & & Cukup Paham & 0 & 0 \\
\hline 3 & & Tidak Paham & 0 & 0 \\
\hline 4 & & Paham & 0 & 0 \\
\hline 5 & & Sangat Paham & 100 & $100 \%$ \\
\hline 1 & \multirow{5}{*}{ Murah Meriah } & Sangat Tidak Paham & 0 & 0 \\
\hline 2 & & Cukup Paham & 0 & 0 \\
\hline 3 & & Tidak Paham & 0 & 0 \\
\hline 4 & & Paham & 0 & 0 \\
\hline 5 & & Sangat Paham & 100 & $100 \%$ \\
\hline
\end{tabular}




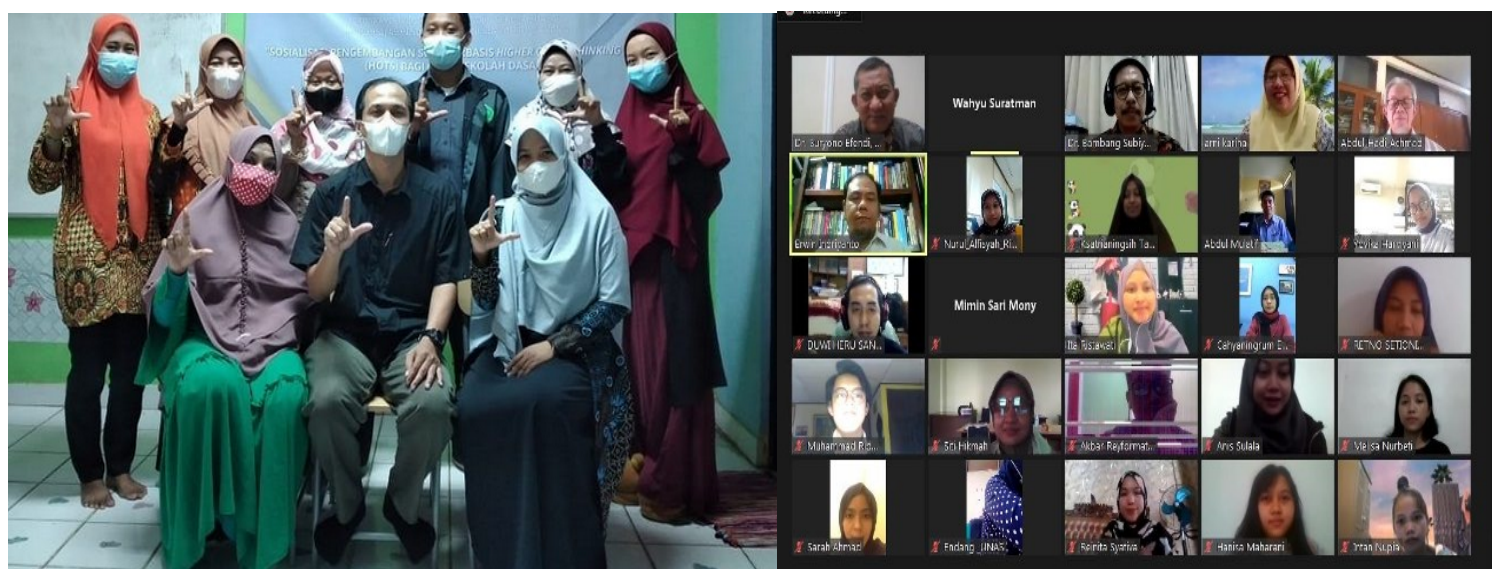

Gambar 1 Tim Mahasiswa dan Dosen yang berada dilokasi dan daring

Kegunaan sebagai obat herbal yang ampuh meredakan sejumlah penyakit seperti kanker.
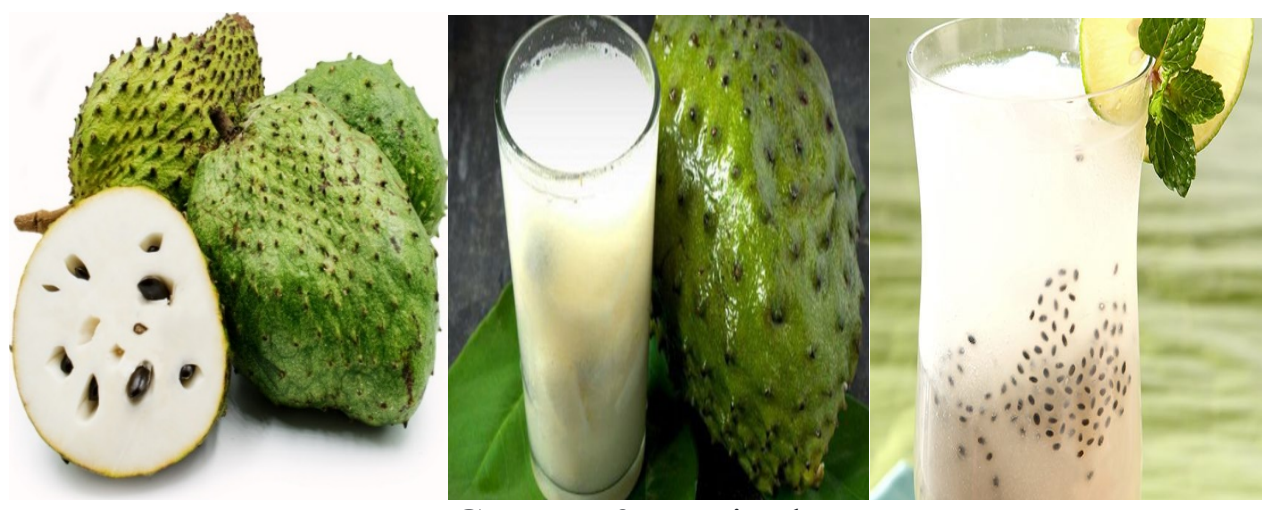

Gambar 2 Jus Sirsak

Kementerian Perdagangan Republik Indonesia (2008) Menyebutkan bahwa buah Sirsak (Annona muricata L.) merupakan tanaman yang bukan berasal dari Indonesia, melainkan dari daratan Amerika Selatan. Beberapa daerah ataupun Negara mengenal buah sirsak dengan nama yang berbeda-beda, seperti soursop, graviola, guanabana dan carossel. Di Indonesia sendiri nama buah sirsak dikenal dengan nama zuursak yang berasal dari bahasa belanda. Beberapa bagian dari tanaman ini seperti daun, biji, buah, akar, sampai kulit batang dapat digunakan sebagai obat-obatan. Tanaman sirsak (Annona muricata L.) dapat tumbuh di sembarang tempat di daerah tropis, tetapi untuk memperoleh hasil buah yang banyak dan berukuran besar sebaiknya sirsak ditanam di daerah yang tanahnya cukup mengandung air. Di Indonesia, sirsak tumbuh dengan baik pada daerah yang mempunyai ketinggian kurang dari 1000 meter. Kementerian Perdagangan Republik Indonesia (2008), menyebutkan bahwa buah sirsak mengandung steroid/terpenoid, flavonoid, kumarin, alkaloid, dan tannin.

Senyawa flavonoid berfungsi sebagai antidiabetes, antioksidan untuk penyakit kanker, anti mikroba, antivirus. Didalam kegiatan ini ada fungsi akuntansi yang mencatat berapa biaya yang dikeluarkan dan berapa hasil penjualan sehingga terlihat area untung atau rugi dari usaha jus Sirsak buat kesehatan. Kemudia Pemerintah daerah dalam hal ini kiranya 


\section{PORTAL RISET DAN INOVASI PENGABDIAN MASYARAKAT (PRIMA) \\ VOLUME 1 ISSUE 1 (2021)}

memperhatikan UKM yang bertumbuh dengan baik agar menambah kegiatan guna mengurangi tigkat pengangguran dikalangan ibu-ibu (Hertati et al., 2020; Howkins, 2005).

Buah sirsak mengandung vitamin dan serat. Vitamin yang terdapat di dalamnya berupa vitamin A, B dan C. selain itu, buah sirsak juga mempunyai beberapa bagian didalamnya yaitu $68 \%$ daging buah yang dapat dimakan, sisanya berupa kulit sebanyak $20 \%$, biji $8,5 \%$, dan empulur 4\% (bagian tengah pada buah sirsak sebagai tempat melekatnya daging buah). Kandungan air pada buah sirsak cukup tinggi yakni sekitar $82 \%$. Beberapa produk olahan yang bisa dibuat dari buah sirsak adalah sari buah, juice, manisan, selai buah sirsak dan lainlain (Kamil \& Putri, 2012).

Buah sirsak juga mengandung zat yang sangat potensial yakni berupa antioksidan. Zat tersebut memiliki peran yang penting dalam tubuh, sebab mampu menghambat reaksi oksidasi dengan mengikat radikal bebas. Selain antioksidan, buah sirsak juga kaya akan vitamin $\mathrm{C}$ dan polifenol. Berdasarkan penelitian yang dilakukan oleh Kementerian Perdagangan Republik Indonesia (2007) dalam 100 gram sari buah sirsak mengandung polifenol sebesar 98,18 mg, 0,77 persen vitamin C dan 282,61 ppm untuk antioksidan. Pada buku yang ditulis oleh Kementerian Perdagangan Republik Indonesia (2008), menyebutkan bahwa buah sirsak bukan hanya dijadikan makanan segar, namun telah dimanfaatkan sebagai bahan industri seperti sirup, manisan, selai, juice, permen jelly, dan campuran kue lainnya yang memiliki nilai tambah, Kementerian Perdagangan Republik Indonesia (2008). Buah sirsak diperkaya dengan vitamin, mineral dan serat pangan. Buah tersebut memiliki ciri-ciri diantaranya adalah kulit berwarna hijau, dagingnya lunak dan berwarna putih serta menghasilkan aroma yang khas. Berikut kandungan gizi dalam 100 gram buah sirsak:

Tabel 2 Kandungan Gizi untuk kesehatan tubuh

\begin{tabular}{cc}
\hline Kandungan & Jumlah \\
\hline Energi & $65,0 \mathrm{kal}$ \\
Protein & $1,0 \mathrm{~g}$ \\
Lemak & $0,30 \mathrm{~g}$ \\
Karbohidrat & $16,30 \mathrm{~g}$ \\
Kalsium & $14,0 \mathrm{mg}$ \\
Fosfor & $27,00 \mathrm{mg}$ \\
Serat & $2,0 \mathrm{~g}$ \\
Besi & $0,60 \mathrm{mg}$ \\
Vitamin A & $1,0 \mathrm{RE}$ \\
Vitamin B1 & $0,07 \mathrm{mg}$ \\
Vitamin B2 & $0,04 \mathrm{mg}$ \\
Vitamin C & $20,0 \mathrm{mg}$ \\
Niacin & $0,70 \mathrm{mg}$ \\
\hline
\end{tabular}

Buah sirsak terbagi menjadi beberapa bagian diantaranya adalah daging buah, kulit buah, biji dan poros tengan (empulur). Selain itu, buah ini juga kaya akan serat. Sekitar 3,3 $\mathrm{g}$ serat terdapat dalam $100 \mathrm{~g}$ buah sirsak. Hal itu dapat memenuhi kebutuhan serat $13 \%$ perhari. Daging buahnya juga mengandung banyak karbohidrat (terutama fruktosa), vitamin C (20 mg/100 g), B1 dan B2 (Teyler, 2002)

\subsection{Preparasi Buah Sirsak}


Daging buah sirsak masak sebanyak $30 \mathrm{~kg}$ diblansir dengan uap air mendidih selama 3 menit. Dari $30 \mathrm{~kg}$ dibuat tiga sediaan yaitu $10 \mathrm{~kg}$ ekstrak etanol 96\%, $10 \mathrm{~kg}$ ekstrak etil asetat dan $10 \mathrm{~kg}$ sari buah. Pembuatan ekstrak etanol dan ekstrak etil asetat dilakukan dengan metode maserasi, ekstrak etanol menggunakan pelarut etanol $96 \%$, ekstrak etil asetat menggunakan pelarut etil asetat, hasil maserasi di rotary evaporator untuk menghilangkan sisa pelarut dan vacum dry untuk menghasilkan ekstrak kental. Sari buah dibuat dengan menyaring daging buah menggunakan kain batis, filtrat hasil penyaringan dianggap sebagai sari buah sirsak $100 \%$. Ketiga sediaan selanjutnya dikarakterisasi dengan melakukan penghitungan rendemen, uji organ oleptik, penetapan kadar abu dan kadar air.

\subsection{Uji Fitokimia}

Sediaan selanjutnya dilakukan uji fitokimia secara kualitatif dan kuantitatif. Uji kualitatif dilakukan untuk kandungan flavanoid, alkaloid, tanin, saponin dan polifenol. Uji kuantitatif dilakukan untuk kandungan polifenol, vitamin C, Kalium dan Natrium. Uji kualitatif flavanoid dilakukan dengan tiga metode yaitu dengan pereaksi $\mathrm{FeCl} 31 \%$, Asam asetat $10 \%$ dan serbuk $\mathrm{Mg}$ dan $1 \mathrm{~mL} \mathrm{HCl}$ pekat. Uji alkaloid dilakukan dengan 3 jenis pereaksi yaitu Dragendroff, Mayer, dan Wagner.Uji tanin dilakukan dengan pereaksiferri klorida $1 \%$ dan uji gelatin. Uji saponin dilakukan dengan uji sabun dan uji hemolisis (Rajendra, 2011). Uji kualitatif untuk polifenol dilakukan dengan larutan ferri klorida 1\%, dan uji kuantitatif kadar Polifenol dilakukan dengan metode Biru Prusi dan penetapan kandungan vitamin $\mathrm{C}$ dilakukan dengan metode titrasi iodometri. Uji kuantitatif kandungan Kalium dan Natrium dilakukan di Balai Penelitian Peternakan Ciawi, Bogor dengan metode AAS.

Tabel 3 Kandugan Gizi Dan Kandungan Zat

\begin{tabular}{|l|c|c|c|}
\hline \multirow{2}{*}{ Jenis Kesediaan } & \multicolumn{3}{|c|}{ Dosis } \\
\cline { 2 - 4 } & $\mathbf{1}$ & $\mathbf{2}$ & $\mathbf{3}$ \\
\hline Sari Buah & $930(\mathrm{a})$ & $1870(\mathrm{~b})$ & $2810(\mathrm{c})$ \\
\hline Ekstra Etanol & $2679(\mathrm{~d})$ & $53,58 €$ & $80,37(\mathrm{f})$ \\
\hline Ekstra Eil Asetat & $2,56(\mathrm{~g})$ & $5,16(\mathrm{~h})$ & $7,75(\mathrm{i})$ \\
\hline Kontrol Positif Tensigard & \multicolumn{3}{|c|}{0,0154 gram $(\mathrm{J})$} \\
\hline Kontrol negatif & \multicolumn{3}{|c|}{$1 \mathrm{ml}$ aguadest (k) } \\
\hline
\end{tabular}

\subsection{Hambatan}

Hambatan dalam pelaksanaan PKM ini adalah kurangnya Keterlibatanan langsung Pemerintah dalam didalam memberi bantuan modal guna menghidupkan wirausaha yang kecil ini, padahal olahan buah Sirsak apabila dikelola diyakini akan menjadi sorotan dunia dan menjadi produk unggulan yang dapat meningkatkan pendapatan masyarakat Kota Palembang jika menjadi olahan pabrik yang berproduksi dalam jumlah besar maka akan mendatangkan laba tinggi. Produk ini merupakan produk olahan buah-buahan yang banyak ditemukan dikebun dan yakin produk ini akan menjadi sorotan dunia dan menjadi produk unggulan yang dapat meningkatkan pendapatan masyarakat oleh karena itu pemasaran menjadi hal utama yang perlu diperbaiki agar produk ini menjad produk yang mendunia 


\section{PORTAL RISET DAN INOVASI PENGABDIAN MASYARAKAT (PRIMA) \\ VOLUME 1 ISSUE 1 (2021)}

\subsection{Solusi}

Untuk menyelasaikan permasalahan yang telah di sampaikan sebelumnya, maka hal yang dilakukan oleh tim adalah dengan cara mengidentifikasikan kebutuhan Mitra dalam hal ini olahan buah Sirsak. Setelah melaksanakan identifikasi maka solusi yang dilakukan dalam hal ini adalah melaksanakan kegiatan pendampingan/ usahawan yang terkait dengan produk ini

\subsection{Dampak Hasil yang Dicapai}

Hasil ekstraksi buah Sirsak menggunakan pelarut etil asetat, didapatkan ekstrak kental sebanyak 16,2 gram (rendemen 1,62 \%), menggunakan pelarut etanol 96\%, didapatkan ekstrak kental sebanyak 149 gram (rendemen 14,9 \%). Pembuatan sari buah sirsak didapatkan sari buah sebanyak 5,2 kg (rendemen 52,2\%), artinya mengandung zigi tinggi dapat mengobati kangker.

\section{KESIMPULAN}

Hasil program yang baik bermanfaat menambah penghasilanpedagang usahan sebagai bagian menanmba pundi-pundi rupiah guna pengetasan garis kemiskinan serta produk yang dihasilkan pun ramah lingkungan dan bergizi tinggi, seperti diketahui warga mulai memanfaatkannya buah sirsak berupa sari buah, ekstrak etanol $90 \%$ dan ektrak etil asetat dapat menurunkan secara nyata kadar asam urat darah tikus jantan maupun betina galur Sprague Dawley. Dosis efektif menurunkan kadar asam urat darah tikus jantan untuk sediaan sari buah semua dosis yang diberikan, untuk ekstrak etanol dosis $2(535,8 \mathrm{mg})$ dan dosis 3 $(803,7 \mathrm{mg})$ dan ekstrak etil asetat hanya dosis $3(77,4 \mathrm{mg})$. Dosis efektif menurunkan kadar asam urat darah tikus betina untuk sediaan sari buah semua dosis yang diberikan, untuk ekstrak etanol 96\% hanya dosis $3(803,7 \mathrm{mg})$ dan ekstrak etil asetat hanya dosis $3(77,4 \mathrm{mg})$. Hasil uji kualitatif, semua sediaan dengan dosis yang berbeda mengandung flavonoid alkaloid, saponin, tanin dan polifenol. Hasil uji kuantitatif menunjukkan sari buah dan ekstrak etanol mengandung polifenol dan vitamin $\mathrm{C}$ tertinggi yaitu 0, 473 (g SAG) dan 38,24 (mg) setiap $100 \mathrm{~g}$ bahan. Disarankan untuk dilakukan uji toksisitas ekstrak etil asetat dan ekstrak etanol 90\% buah sirsak. Perlu dikembangkan juga untuk membuat sediaan farmasi sari buah, ekstrak etil asetat dan ekstrak etanol 90\% buah sirsak yang lebih praktis, kontinjuitas terjamin yang dapat digunakan sebagai obat penurunan kadar asam urat darah.

\section{Ucapan Terima Kasih}

Terima kasih kepada ibu-ibu pedagang eceran jus buah Sirsak yang telah bersedia didatangi guna mengadakan pelatihan Usahawan manfaat yang dikandung buah Sirsak untuk kesehatan tubuh dengan harga yang tidak terlalu mahal namun terjangkau oleh anak-anak sekolah dan kaulah mudah, dan apabilah ditambah dengan susu dan biji selasi akan menanbah nikmat yang tiada tarah.

\section{DAFTAR PUSTAKA}

Ashari, S. (2006). Meningkatkan Keunggulan Bebuahan Tropis Indonesia. Andi. Dahliani, D. (2015). Local wisdom in built environment in globalization era. International Journal of Education and Research, 3(6). 
Hertati, L., Asmawati, A., \& ... (2021). Peran sistem informasi manajemen di dalam mengendalikan operasional badan usaha milik daerah. Insight Management ..., 1(2).

Hertati, L., Feri, I., Puspitawati, L., Gantino, R., \& Ilyas, M. (2021). Pengembangan UMKM Unggulan Gambomuba Produk Lokal Guna Menopang Perekonomian Rakyat Akibat COVID-19. Indonesia Berdaya, 2(1), 55-68.

Hertati, L., Mustopa, I. M., Widiyanti, M., \& Safkaur, O. (2020). The Effect of Accounting Information System Applications in the Industrial Revolution Era 4. 0 Influenced by the Organizational Structure of the period Covid-19. Indo-Asian Journal of Finance and Accounting, 1(2), 125-151.

Hertati, L., \& Safkaur, O. (2020). Dampak Revolusi Industri 4.0 Era Covid-19 pada Sistem Informasi Akuntansi Terhadap Struktur Modal Perusahaan. Jurnal Riset Akuntansi Dan Keuangan, 8(3). https://doi.org/10.17509/jrak.v8i3.23557

Howkins, J. (2005). The Creative Economy: Knowledge-Driven Economic Growth India: Jodhpur.

Kamil, A., \& Putri, R. (2012). Sistem Spasial Industri Kreatif Berbasis Kearifan Lokal Dalam Rangka Meningkatkan Kompetitive Advantage Nasional. Prosiding SNKIB II Untar, 2(1), 151-160.

Kementerian Perdagangan Republik Indonesia. (2007). Studi Industri Kreatif Indonesia. In Jakarta: Kementerian Perdagangan RI.

Kementerian Perdagangan Republik Indonesia. (2008). Pengembangan Ekonomi Kreatif Indonesia 2025. In Jakarta: Kementerian Perdagangan RI.

Kementerian Perdagangan Republik Indonesia. (2008). Program Kerja Pengembangan industri Kreatif Nasional 2009-2015. Kementerian Perdagangan RI.

Khristianto, W. (2008). Peluang dan Tantangan Industri Kreatif Indonesia. Jurnal Bisnis Dan Manajemen, 5(1), 33-48.

Kuncoro, M. (2001). Metode Kuantitatif: Teori dan Aplikasi Untuk Bisnis dan Ekonomi. AMP YKPN.

Maria. (2013). Kandungan Nutrisi dan Manfaat Buah Sirsak Untuk Kesehatan.

Naylor, T. D., \& Florida, R. (2003). The Rise of the Creative Class: And How It's Transforming Work, Leisure, Community and Everyday Life. Canadian Public Policy / Analyse de Politiques, 29(3). https://doi.org/10.2307/3552294

Prasetyorini, Moerfiah, Wardatun, S., \& Affandi. (2014). Aktifitas Berbagai Sediaan Buah Sirsak (Annona muricata Linn) Dalam Penurunan Kadar Asam Urat Tikus Putih Sprague-Dawley. Ekologia, 14(2). https://core.ac.uk/download/pdf/229274861.pdf

Teyler, L. (2002). Herbal Secrets of The Rainforest. 